\title{
Whole-tree biomass and carbon allocation of juvenile trees of loblolly pine (Pinus taeda): influence of genetics and fertilization
}

\author{
W.A. Retzlaff, J.A. Handest, D.M. O'Malley, S.E. McKeand, and M.A. Topa
}

\begin{abstract}
To assess the contribution of belowground biomass allocation towards total carbon (C) allocation of two provenances of loblolly pine (Pinus taeda L.), we examined the total biomass allocation of a fast- and slow-growing family from each provenance. Since planting on a xeric, infertile site in Scotland County, N.C., U.S.A., trees in this study have been subjected to one of two nutrient treatments: optimal nutrition or control (no fertilization). Total biomass of 24 (1 tree/family plot $\times 2$ families $\times 2$ provenances $\times 2$ treatments $\times 3$ blocks) 5 -year-old (juvenile) trees was harvested in January 1998. Fertilization increased total root, total shoot, and total tree biomass in all families as compared with harvested trees in control plots. Fertilization also increased biomass of coarse-root, woody-root, taproot, stem, branch, and foliar components of families as compared with trees in control plots. Although there were treatment and family differences in standing-crop biomass of the total root, total shoot, total tree, and various individual root and shoot components, the percent biomass (whole-tree) allocation to these tissues remained similar across treatments. Total nonstructural carbohydrate (TNC) analysis indicated some treatment, family, and provenance differences in TNC concentrations and partitioning to starch and soluble sugars. At the time of harvest, TNC concentrations of belowground tissues were much higher than those of aboveground tissues, and enhanced partitioning towards starch in root tissues indicates an important $\mathrm{C}$ storage role for belowground tissues at this time. Indeed, more than $90 \%$ of the trees starch content was present in root tissue in January. Although constrained by a sample size of three harvested trees per family, this study suggests that biomass allocation on a whole-tree level was similar between fast- and slow-growing families of different provenances of juvenile loblolly pine and was not affected by fertilizer treatment.

Résumé : De façon à évaluer la contribution de l'allocation en biomasse souterraine à celle de la biomasse totale de deux provenances de pin à encens (Pinus taeda L.), nous avons examiné l'allocation de la biomasse totale d'une famille à croissance rapide et d'une famille à croissance lente pour chaque provenance. Depuis leur plantation sur un site xérique et pauvre du comté de Scotland en Caroline du Nord, aux États-Unis, les arbres de cette étude ont été soumis à un des deux traitements de fertilisation suivants : nutrition optimale ou témoin (pas de fertilisation). La biomasse totale de 24 arbres ( 1 arbre par placette représentant une famille $\times 2$ familles $\times 2$ provenances $\times 2$ traitements $\times 3$ blocs) âgés de 5 ans (arbres juvéniles) a été récoltée en janvier 1998. La fertilisation a causé l'augmentation de la biomasse racinaire totale, aérienne totale et de l'arbre entier dans toutes les familles, en comparaison avec les arbres récoltés dans les placettes-témoins. Pour chaque famille, la biomasse des racines grossières, des racines lignifiées, de la racine pivotante, de la tige, des branches et du feuillage a également augmenté avec la fertilisation, en comparaison avec les arbres dans les placettes-témoins. Bien qu'il y eut des différences au niveau des placettes entre les traitements et les familles quant à la biomasse racinaire totale, aérienne totale et de l'arbre entier et quant aux différentes composantes individuelles aériennes et souterraines, l'allocation relative de la biomasse à ces tissus est restée similaire, indépendamment des traitements. Une analyse des sucres totaux non structuraux (TNC) a révélé quelques différences entre les traitements, les familles et les provenances quant aux concentrations de TNC et quant à la partition entre l'amidon et les sucres solubles. Au moment de la récolte, les concentrations en TNC des tissus souterrains étaient beaucoup plus élevées que celles des tissus aériens, et une partition plus élevée des TNC en amidon dans les tissus racinaires montre bien le rôle important de stockage du carbone dans les tissus souterrains au moment de la récolte. En effet, plus de $90 \%$ du contenu en amidon des arbres était situé dans les tissus racinaires au mois de janvier. Bien que limitée par la taille de l'échantillonnage (trois arbres récoltés par famille), cette étude indique que l'allocation de la biomasse au niveau de l'arbre entier est similaire entre des familles à croissance rapide ou lente issues de provenances différentes de pins à encens juvéniles et qu'elle n'est pas influencée par la fertilisation.
\end{abstract}

[Traduit par la Rédaction]

Received June 9, 2000. Accepted January 8, 2001. Published on the NRC Research Press Web site on May 29, 2001.

W.A. Retzlaff ${ }^{1,2}$ and M.A. Topa. Boyce Thompson Institute for Plant Research, Tower Road, Ithaca, NY 14853-1801, U.S.A. J.A. Handest, D.M. O'Malley, and S.E. McKeand. Department of Forestry, College of Forest Resources, North Carolina State University, Raleigh, NC 27695-8002, U.S.A.

${ }^{1}$ Corresponding author (e-mail: WRETZLA@ @iue.edu).

${ }^{2}$ Present address: Environmental Science Program, Department of Biological Sciences, Southern Illinois University Edwardsville, Box 1099, Edwardsville, IL 62026-1099, U.S.A. 


\section{Introduction}

Loblolly pine (Pinus taeda L.) is one of the most important tree species in the southern region of the U.S.A., with over 800000000 seedlings planted annually (McKeand et al. 1999). Within this region, plantations of genetically improved trees have been recognized as being critical in providing reliable, ecologically sustainable, and economically affordable wood supplies. To this end, great effort has been expended to maximize productivity through genetic selection of trees with traits that maximize capture of carbon $(\mathrm{C})$ and conversion into standing-crop biomass. Genetic gains from tree improvement programs have been large (e.g., McKeand and Svensson 1997) because geographic and within-provenance variation for growth and adaptive traits in loblolly pine is large. In most provenance tests, trees of coastal origins have consistently outgrown trees of continental origin and trees of southern origins have outgrown those of northern origins; differences in dry mass allocation in seedlings have been found to account for some, but not all, of the observed differences (Bongarten and Teskey 1987). Studies examining differences in whole-tree biomass allocation with an emphasis on belowground components in fieldgrown trees are lacking. Strong genetic control of biomass and $\mathrm{C}$ allocation and partitioning to aboveground and belowground components may influence a tree's ability to compete for resources (i.e., light, nutrients, and moisture) and withstand environmental stress. Because of the episodic nature of shoot and root growth in trees (Drew and Ledig 1980), storage C plays a critical role in buffering day-to-day and seasonal fluctuations in the carbohydrate supply to particular tissues. If an environmental stress such as soil fertility or drought decreases the photosynthetic capacity of a plant, then $\mathrm{C}$ reserves may be used to supplement growth demands. Balanced allocation of $\mathrm{C}$ between immediate use and storage is essential for plant growth and survival during seasonal fluctuations in C supply and stress episodes (Geiger and Servaites 1994).

Several studies have associated variation in yield among families of loblolly pine seedlings with net assimilation rate, water-use and nutrient-use efficiency, and aspects of aboveground dry matter allocation (Bongarten and Teskey 1987; Greenwood and Volkaert 1992; Li et al. 1991). How genetically based differences in belowground $\mathrm{C}$ allocation and partitioning may influence yield has not been examined in fieldgrown trees. Open-pollinated families of loblolly pine selected from the western extent of the physiographic range (Lost Pines, Texas (LPT)) and Atlantic Coastal Plain (ACP) provenances were recently established on a droughty, infertile site in the Sandhills of North Carolina (McKeand et al. 1999). After 4 years, the ACP families were significantly taller and had greater stem volume than the LPT families in control and optimally fertilized plots. Since annual fine-root production and maintenance costs in trees can be as much as $60-80 \%$ of the total net primary productivity of forests (Reichle et al. 1973; Ågren et al. 1980), yield variation in aboveground production among families could be associated with differences in belowground $\mathrm{C}$ demands. Evidence from physiological analyses of seedling traits suggests that drought-hardy LPT families owe their drought hardiness to various avoidance mechanisms, including deep root systems and wide-ranging laterals (van Buijtenen et al. 1976). Other seedling studies also indicate that LPT families allocate more $\mathrm{C}$ to root growth compared with ACP families, regardless of soil stresses and soil fertility (Topa and Sisak 1997). Whether these differences in whole-tree biomass allocation are maintained in the field as a tree matures is unknown. Further, the question of how fertilization can affect the biomass allocation of differing genotypes has previously been unanswered.

Presumably, extra $\mathrm{C}$ becomes available for aboveground growth under fertilized conditions because root system $\mathrm{C}$ demands resulting from fine-root production and mycorrhizal colonization decreases. Recent investigations using minirhizotron root observation tubes in the field suggest that the effects of fertilization on root production and turnover may be species, age, and stand specific (Pregitzer et al. 1993; Majdi and Nylund 1996; Tingey et al. 1996; Johnson et al. 2000). Theoretically, populations that allocate more $\mathrm{C}$ below ground, such as the drought-hardy LPT provenance, could benefit the most from soil amendments if whole-tree biomass allocation is plastic. However, seedling studies with the LPT population suggest that its biomass allocation, root ontogeny, and root architecture are under strong genetic control, regardless of the external soil environment (Topa and Sisak 1997).

Identifying how whole-tree $\mathrm{C}$ source-sink relationships may change with age and edaphic stress, with an emphasis on root system $\mathrm{C}$ demands, is central to any genetic regulation of photosynthate to harvestable (e.g., stem or bole) and nonharvestable tissues. In the study reported herein, we examined whole-tree (total standing-crop) biomass and tissue carbohydrate concentrations to compare possible differences in structural and nonstructural $\mathrm{C}$ allocation and partitioning between fast- and slow-growing families from two provenances of loblolly pine planted in a droughty, infertile site in North Carolina, U.S.A. More specifically, we examined whether genetically based differences in aboveground yield reflected differences in whole-tree biomass allocation and whether fertilization would alter biomass allocation patterns. We hypothesized that (1) drought-hardy trees from Texas (LPT) preferentially allocated more biomass below ground than did trees from the Atlantic Coastal Plain (ACP) and (2) that fertilization would reduce allocation to roots, more specifically to fine-root biomass.

\section{Methods}

\section{Study site}

The study site is known as SETRES2 and is located in Scotland County, N.C., U.S.A., adjacent to the USDA Forest Service North Carolina State University Southeastern Tree Research and Education Site (SETRES; see Albaugh et al. 1998). The soil is a Wakulla series (sand to $>43 \mathrm{~m}$; sandy, siliceous, thermic Psammentic Hapludult), very infertile, somewhat excessively drained with a total water-holding capacity of $12-14 \mathrm{~cm}$ in a $2-\mathrm{m}$ profile. The site receives an average annual precipitation of $1200 \mathrm{~mm}$. Temperatures average $17^{\circ} \mathrm{C}$ annually, with seasonal averages of $26^{\circ} \mathrm{C}$ in summer and $9^{\circ} \mathrm{C}$ in winter. An existing 10-year-old loblolly pine stand was removed, and large block plots of different familytreatment combinations were established on this droughty, infertile site. Five open-pollinated families from the North Carolina and South Carolina Atlantic Coastal Plain (ACP) and five drought-hardy Texas families (LPT) with average or slightly above-average breed- 
Fig. 1. Mean biomass data from whole-tree harvest in January 1998 for each of the four loblolly pine families in control (C) and fertilized (F) plots. (a) Total root and shoot biomass; (b) stem, branch, and foliage biomass; and (c) taproot, woody-root, coarse-root, and fine-root biomass. ACP, Atlantic Coastal Plain families; LPT, drought-hardy Texas families; 1 , fast growing; 2 , slow growing; $n=3$. $P$ values are reported in Table 1.

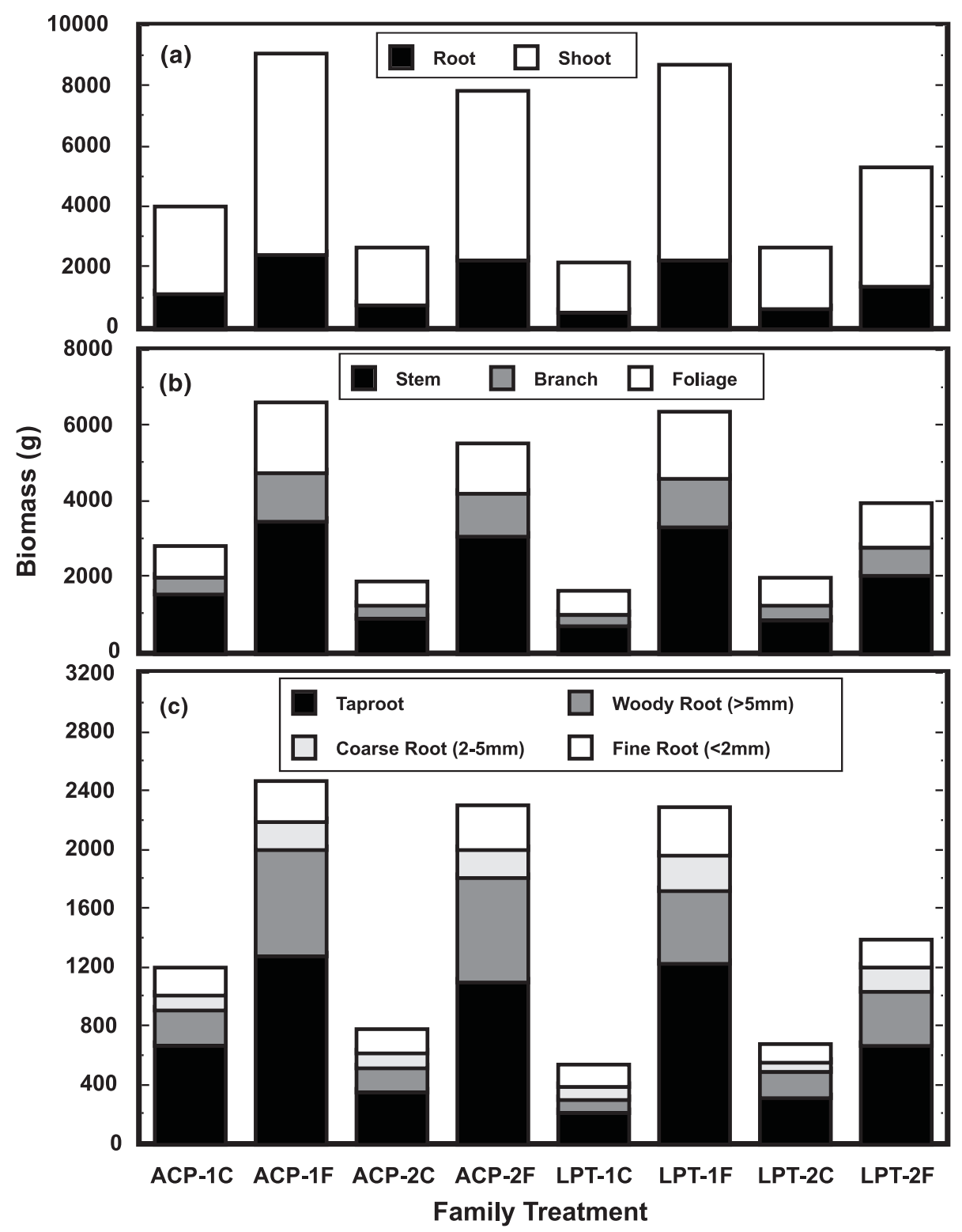

ing values for volume production were selected for this study. Breeding values across the 10 families ranged from 8.6 to -9.3 based upon aboveground height growth at 4 years of age (breeding value $=$ mean family height at 4 years - mean height of all families at 4 years) (McKeand et al. 1999). Seeds were sown in containers $\left(160 \mathrm{~cm}^{3}\right.$ RL Super Cells) in the greenhouse in June 1993, and seedlings were field-planted in November 1993.

The experimental design of the field site is 10 blocks $\times 2$ provenances $(\mathrm{ACP}, \mathrm{LPT}) \times 5$ families/provenance (fast and slow growing) $\times 2$ fertilizer treatments (unfertilized and optimum fertilization) with 100 trees in each family plot for a total of 20000 trees. Each family plot consists of 10 rows of 10 trees planted at $1.5 \times 2 \mathrm{~m}$ spacing. The tight spacing was necessary because of space limitations and the required 100 trees/family per treatment was necessary for the quantitative trait locus objectives in the study. One-half of each one of the blocks have received annual soil fertilizer additions to maintain optimum foliar nutrient ratios (Hockman and Allen
1990), while control plots have received no nutrient additions Through the first four growing seasons, total nutrient additions (kg/ha) have been $240 \mathrm{~N}, 45 \mathrm{P}, 85 \mathrm{~K}, 3 \mathrm{Ca}, 20 \mathrm{Mg}, 35 \mathrm{~S}, 0.5 \mathrm{~B}, 2$ $\mathrm{Cu}, 5 \mathrm{Fe}, 5 \mathrm{Mn}$, and $2 \mathrm{Zn}$.

For the current study, we selected the fastest- and slowestgrowing families from each provenance, based upon evaluation of aboveground height growth of control trees at 4 years of age (McKeand et al. 1999). Families ACP-1 (8-1118) and ACP-2 (91046) were the fast- and slow-growing ACP families, respectively, and LPT-1 (BA3L11-1) and LPT-2 (GR1-2) were the fast- and slow-growing LPT families, respectively (4-year heights: ACP-1, $183 \pm 1.7 \mathrm{~cm}$; ACP-2, $165 \pm 1.7 \mathrm{~cm}$; LPT-1, $165 \pm 1.5 \mathrm{~cm}$; LPT-2, $157 \pm 1.6 \mathrm{~cm}($ mean $\pm \mathrm{SE}))$. We also focused our analysis on three blocks $(6,8$, and 10$)$ of this large study because sample size constrained data collection. Average aboveground growth in these three blocks closely approximated the overall study for 4-year aboveground growth (data not shown). 
Table 1. $P$ values from the ANOVA for biomass (Fig. 1) and percent of total biomass (Fig. 2) of the component tissues from whole-tree harvest in January 1998.

\begin{tabular}{lllll}
\hline & $P>F$ & & \\
\cline { 2 - 4 } & Treatment & Provenance & $\begin{array}{l}\text { Family } \\
\text { (provenance) }\end{array}$ & $\begin{array}{l}\text { Treatment } \times \\
\text { provenance }\end{array}$ \\
\hline Biomass & & & & \\
Total shoot & 0.0257 & 0.4249 & 0.0277 & 0.5902 \\
Total root & 0.0101 & 0.1957 & 0.0057 & 0.4548 \\
Stem & 0.0251 & 0.2276 & 0.0030 & 0.5077 \\
Branch & 0.0089 & 0.6311 & 0.2546 & 0.3776 \\
Total foliage & 0.0589 & 0.7537 & 0.1050 & 0.8207 \\
Taproot & 0.0245 & 0.2148 & 0.0405 & 0.9790 \\
Coarse root & 0.0081 & 0.9555 & 0.0664 & 0.6004 \\
Woody root & 0.0005 & 0.1016 & 0.5715 & 0.0611 \\
Fine root & 0.1072 & 0.3867 & 0.1505 & 0.9496 \\
\% of total biomass & & & & 0.3783 \\
$\%$ stem & 0.1648 & 0.6599 & 0.8530 & 0.3734 \\
$\%$ branch & 0.3520 & 0.9360 & 0.6399 & 0.3781 \\
$\%$ foliage & 0.2321 & 0.0460 & 0.9696 & 0.1442 \\
$\%$ taproot & 0.7199 & 0.0171 & 0.3110 & 0.9418 \\
$\%$ coarse root & 0.2149 & 0.0809 & 0.1407 & 0.1129 \\
$\%$ woody root & 0.1744 & 0.0348 & 0.0184 & 0.1977 \\
$\%$ fine root & 0.4026 & 0.3555 & 0.3196 &
\end{tabular}

\section{Biomass harvest}

Twenty-four trees ( 1 tree/family plot $\times 2$ families $\times 2$ provenances $\times 2$ treatments $\times 3$ blocks) were harvested in January 1998 . Trees were selected for harvest from an outside row of the 100-tree plot. Selected trees represented the mean height of all trees in the immediate plot. Trees were cut at the groundline, and aboveground biomass was sorted into foliage (age-class), branch, and stem components. Roots within a $1 \times 1 \mathrm{~m}$ square centered around the trunk were excavated at two depths $(0-20$ and $21-40 \mathrm{~cm})$ into buckets and sifted consecutively through $1.3-$ and $0.64-\mathrm{cm}$ mesh screens. Only lateral roots emanating from the harvested taproot were collected; lateral roots within the $1-\mathrm{m}^{2}$ plot from other trees were excluded. Since there was competing vegetation in the stand, roots of other species (based upon color and appearance) were removed during the sifting process. Sifted loblolly roots were sorted by size class: <2 $\mathrm{mm}$ (fine roots), $2-5 \mathrm{~mm}$ (coarse roots), $>5 \mathrm{~mm}$ (woody roots). Any remaining lateral roots (below $40 \mathrm{~cm}$ soil depth) and the entire taproot were then excavated. All tissues (above- and belowground components) were oven-dried and weighed to obtain standing-crop biomass estimates.

\section{Carbohydrate analysis}

Just prior to harvest, tissue samples were collected from two trees per family plot between 1100 and $1700 \mathrm{~h}$ (including one tree from total-tree harvest) for carbohydrate analysis. Foliar samples of the first two 1997 flushes were collected from three branches in the upper third of the canopy from the two trees. Stem cores $(4.3 \mathrm{~mm})$ were removed with an increment borer from the bole of both trees between the fourth and fifth branch whorl (at or just below breast height, i.e, approximately $1.3 \mathrm{~m}$ ). Branch tissue from three branches was collected at the base of the sterile node of the 1997 first flush from both selected trees. Taproot cores were removed with an increment borer $10 \mathrm{~cm}$ below the whorl of lateral roots nearest the soil surface from both trees. Four soil cores (per tree) were removed within a $30 \mathrm{~cm}$ radius of the bole of two trees per family $\times$ treatment plot using an AMS (Art's Manufacturing and Supply, American Falls, Idaho) auger $(5.0 \mathrm{~cm}$ diameter) in the $0-20 \mathrm{~cm}$ soil horizon before the trees were harvested. Roots from these cores were sorted from other species as above, sifted consecutively through $1.3-$ and $0.6-\mathrm{cm}$ screens, sorted into fine $(<1.0 \mathrm{~mm})$ and coarse $(>1.0 \mathrm{~mm})$ roots, and washed in cold water. We have found that total nonstructural carbohydrate (TNC) concentrations do not vary between size classes $>1 \mathrm{~mm}$ (unpublished data); consequently, we used a smaller diameter classification system for carbohydrate analysis of fine roots, and pooled all roots larger than $1 \mathrm{~mm}$ as "coarse roots." Dead roots and all roots that were not loblolly pine roots were removed. Above- and below-ground tissues for carbohydrate analysis were placed immediately on dry ice and stored at $-70^{\circ} \mathrm{C}$ until tissue was freeze-dried.

Freeze-dried tissue was ground with a SPEX ${ }^{\circledR}$ CertiPrep 8500 shatterbox. The dry mass of the ground roots was recorded, and root density in the $0-20 \mathrm{~cm}$ depth of the four pooled soil cores was calculated. Ground tissue was extracted with $80 \%$ ethanol at $80^{\circ} \mathrm{C}$ and centrifuged for $10 \mathrm{~min}$ at $3000 \mathrm{~g}$ (Topa and Cheeseman 1992a). Reducing sugars (glucose + fructose) and sucrose were determined in the ethanol extract using enzymatic analysis (Jones et al. 1977). The starch-containing tissue pellet was incubated with amyloglucosidase for $24 \mathrm{~h}$ at $55^{\circ} \mathrm{C}$ and centrifuged. Starch concentrations in the tissue were determined as glucose equivalents using enzymatic analysis. TNC concentrations represent the sum of starch, reducing sugars, and sucrose concentrations.

\section{Statistical analysis}

The entire experiment is a split-plot design with treatment as the main plot, provenance as subplots, and families nested within provenance. Analysis of variance of total and component biomass and carbohydrate content was conducted using $\mathrm{SAS}^{\circledR}$ on a plot-mean basis.

\section{Results and discussion}

\section{Standing-crop biomass}

As expected, fertilization increased (Fig. 1, Table 1) aboveground biomass of all four families, corresponding with the previously reported increase in height and volume (McKeand et al. 1999). Within a provenance in the fertilized plots, the 
Fig. 2. Mean percentage of tree biomass allocated to component tissues from whole-tree harvest in January 1998 for each of the four loblolly pine families in control (C) and fertilized (F) plots. (a) Stem, branch, and foliage biomass and (b) taproot, woody-root, coarseroot, and fine-root biomass. Other information as in Fig. 1. $P$ values are reported in Table 1.

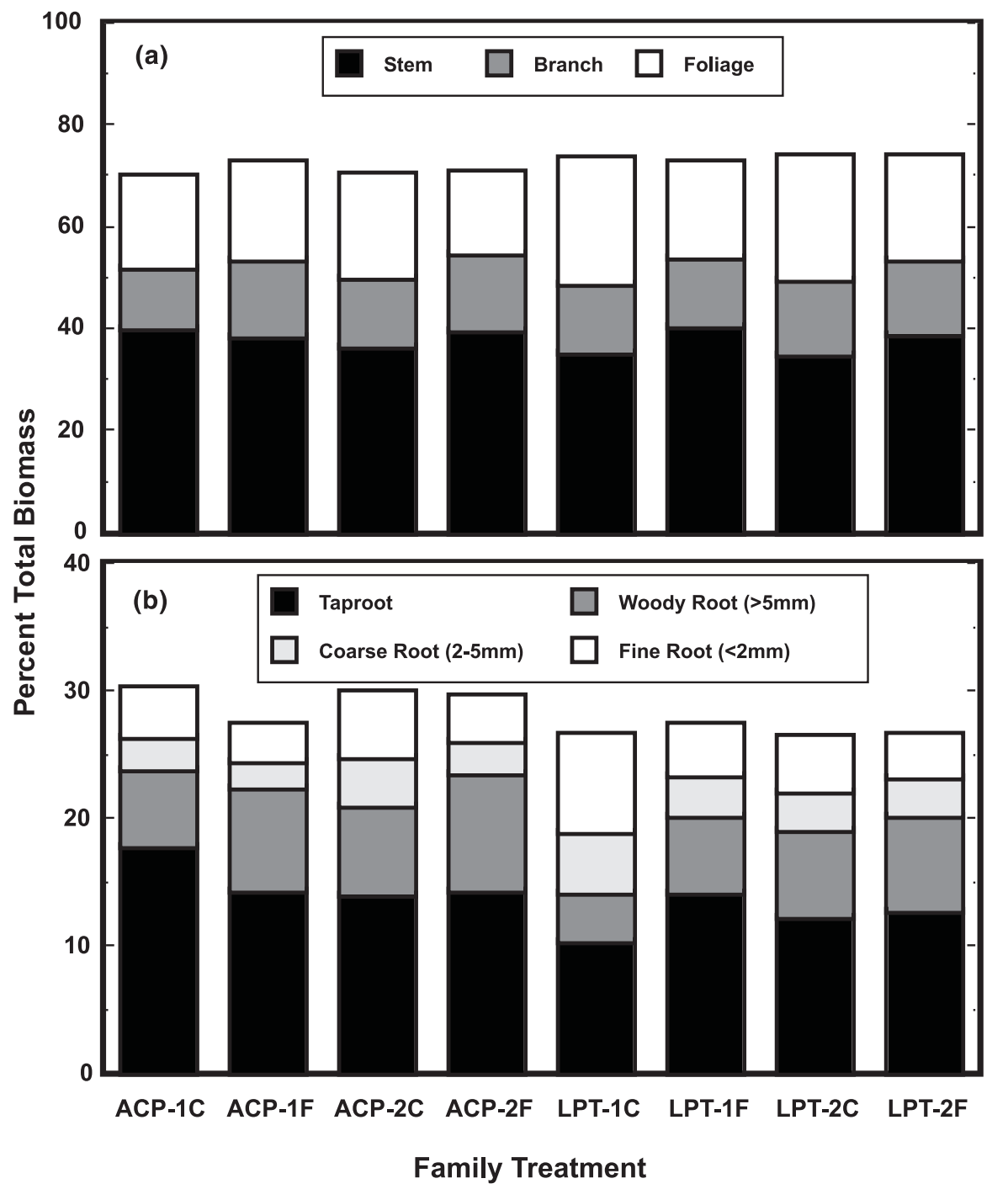

two harvested faster-growing families had greater aboveground biomass (ACP-1, 6532 $\pm 277 \mathrm{~g}$ and LPT-1, $6327 \pm$ $1637 \mathrm{~g}$ ) than their slower-growing counterparts (ACP-2, $5468 \pm 185 \mathrm{~g}$ and LPT-2, $3882 \pm 483 \mathrm{~g})$. As reported previously for aboveground production, (McKeand et al. 1999), the two ACP families clearly performed as well or better than the LPT families in terms of total aboveground biomass accumulation in both poor and enriched nutrient environments (Fig. 1, Table 1). It remains to be seen, as the trees shift from the juvenile to the mature life stage and the competition for light and soil resources increases, whether aboveground growth of these families or provenances will remain altered by fertilization.

Although many studies have reported aboveground biomass estimates of loblolly pine (e.g., Shelton et al. 1984; Van Lear et al. 1986; Baldwin 1987; Van Lear and Kapeluck 1995; Albaugh et al. 1998), few have reported belowground biomass estimates for loblolly pine in the field (e.g., Harris et al. 1977; Van Lear and Kapeluck 1995; Albaugh et al. 1998) and none from known genetic origin as in the current study. In the present study, fertilization increased the standingcrop biomass of belowground tissues of all families (Fig. 1, Table 1) and total tree biomass as well. Similar to the aboveground response, the two faster-growing families had greater belowground biomass (ACP-1, $2455 \pm 95 \mathrm{~g}$ and LPT-1, $2278 \pm 458 \mathrm{~g}$ ) than their slow-growing counterparts (ACP-2, $2284 \pm 75 \mathrm{~g}$ and LPT-2, $1377 \pm 112 \mathrm{~g}$ ) under fertilized conditions (Fig. 1, Table 1). In fact, under fertilized conditions, the faster-growing LPT family (LPT-1) grew as well as both the ACP families (e.g., above- and below-ground biomass was similar).

Interestingly, although there were treatment and family differences in the standing-crop biomass of the root, shoot, and various components, percent (whole-tree) allocation to these tissues was the same across treatments (Fig. 2, Table 1). Fertilization increased the standing-crop biomass of all tissues except fine roots (Fig. 1, Table 1), but aboveground biomass did not appear to increase at the expense of belowground compartments or vice versa (Fig. 2). Our root biomass and whole-tree estimates will underestimate total 
Table 2. Percent of total tree biomass allocated to roots in loblolly pine stands of various ages and site amendments.

\begin{tabular}{lllll}
\hline $\begin{array}{l}\text { Stand age } \\
\text { (years) }\end{array}$ & $\begin{array}{l}\% \text { of biomass } \\
\text { in roots }\end{array}$ & Amendments & Method* $^{*}$ & Study \\
\hline 5 & $<30$ & None, fertilization & 1 & Current study \\
$9-11$ & $23-35$ & None, fertilization, irrigation & 2 & Albaugh et al. 1998 \\
15 & 24 & None & 3 & Harris et al. 1977 \\
48 & 20 & None & 4 & Van Lear and Kapeluck 1995 \\
\hline
\end{tabular}

$* 1$, whole-tree excavation of all root classes; 2 , whole-tree excavation of all root classes $>2$ mm, fine roots scaled from cores; 3, whole-tree excavation of a small number of trees plus block excavation and allometry; 4, minimal whole-tree excavation of some classes of roots, allometry used to predict lateral root size classes, and roots $\leq 0.6 \mathrm{~cm}$ estimated from cores.

Table 3. Comparison of actual vs. estimated lateral-root density measurements in the $0-20 \mathrm{~cm}$ soil horizon in a $1-\mathrm{m}^{2}$ plot around the taproot of each harvested tree.

\begin{tabular}{llll}
\hline & \multicolumn{2}{l}{ Lateral-root density $\left(\mathrm{g} \cdot \mathrm{m}^{-3}\right)$} \\
\cline { 2 - 4 } Family & Treatment & Harvest & Soil coring \\
\hline ACP 1 & Control & $1989 \pm 510$ & $1000 \pm 216$ \\
& Fertilized & $4953 \pm 128$ & $2036 \pm 482$ \\
ACP 2 & Control & $1673 \pm 332$ & $1073 \pm 194$ \\
& Fertilized & $4930 \pm 449$ & $3981 \pm 866$ \\
LPT 1 & Control & $1319 \pm 147$ & $1009 \pm 194$ \\
& Fertilized & $3826 \pm 544$ & $1686 \pm 358$ \\
LPT 2 & Control & $1175 \pm 205$ & $1076 \pm 390$ \\
& Fertilized & $2660 \pm 290$ & $2929 \pm 419$ \\
\hline
\end{tabular}

Note: Comparisons are made between lateral-root density measurements obtained from whole-tree harvest extraction vs. soil coring methods. Values are means \pm SE, $n=3$ for whole tree harvest and $n=6$ for soil coring. For soil coring data, $n$ represents four pooled samples.

root allocation, since we only harvested the lateral-root biomass from the $1 \mathrm{~m}^{3}$ soil volume around each tree. However, based on tree canopy size and tracing of lateral roots outside some $1 \mathrm{~m}^{3}$ soil volumes, we estimate that over 90 and $85 \%$ of the total root biomass were harvested in trees from the control and fertilized plots, respectively. This would not change family or provenance comparisons of biomass allocation and would only slightly affect treatment comparisons.

Our hypothesis that the drought-hardy LPT trees would preferentially allocate more biomass belowground than the ACP trees was not supported by the whole-tree standing-crop biomass data. However, our results estimate standing-crop biomass at a single time point during the growing season and life-span of these trees and also underestimate total root biomass. Further, our constrained sample size limits our conclusions regarding family-provenance differences $(n=3$ and $n=$ 6 , respectively), but not treatment differences $(n=12)$.

The percentage of total tree biomass allocated to shoot and root tissues in the current study (>70\% for shoot tissue and $<30 \%$ for root tissue, in all families and treatments, Fig. 2) corresponds very closely with values reported in a number of other biomass harvest studies representing a widerange of ages and sites within the physiographic region of loblolly pine (Table 2). Whole-tree standing-crop biomass estimates based on total shoot plus some limited root data from trees of different ages from North Carolina, Mississippi, Alabama, Louisiana, and South Carolina, U.S.A. have reported similar belowground and aboveground biomass al- location (Shelton et al. 1984; Van Lear et al. 1986; Baldwin 1987; Van Lear and Kapeluck 1995; Albaugh et al. 1998). Loblolly pine has a more or less "fixed" structural biomass allocation (ca. $70-80 \%$ above ground and $20-30 \%$ below ground), regardless of age and site characteristics.

The cross-study comparison of data would suggest that percent biomass allocation to roots of loblolly pine decreases as trees age. However, caution must be exercised when interpreting these data because of the increased difficulty in extracting the entire root system of trees as they age. Thus, studies are more likely to underestimate standing-crop biomass of root systems as trees mature because of a stronger reliance on indirect methods for estimating root biomass than on direct methods (as used in the current study). Of the four studies in Table 2, the current study was the only one that actually harvested all root classes, including taproots and lateral roots $<5 \mathrm{~mm}$ diameter, and did not depend upon soil coring and allometric techniques to predict biomass of the various root classes. Although whole-tree excavation may give limited information on a stand level (Vogt and Persson 1991), it provides better individual-tree estimates than soil cores or monolith methods on root distribution throughout the soil profile, on total root biomass, and on the percentage of total root biomass allocated to the various root classes (e.g., taproot, coarse roots, fine roots, etc.). Good estimates of the biomass of roots larger than $2 \mathrm{~mm}$ in diameter are difficult to obtain from cores because these larger roots are often not distributed uniformly and decrease in density with increasing distance from the taproot (Vogt and Persson 1991).

The soil coring data in the current study (Table 3) would support Vogt and Persson's (1991) conclusion that soil coring may provide better estimates of fine-root (i.e., roots $\leq 2 \mathrm{~mm}$ ) biomass at the stand level than at an individual-tree level, assuming a sufficient number of cores are removed in a stand. In the current study, although lateral-root density for the harvested tree was highest in the upper $0-20 \mathrm{~cm}$ of the $1-\mathrm{m}^{2}$ plot, we consistently underestimated lateral-root density within that $1-\mathrm{m}^{2}$ plot using soil cores even though we sampled a soil volume that would have had the highest density of lateral roots (Table 3). Because lateral-root distribution in the $21-40 \mathrm{~cm}$ soil depth was less than $30 \%$ (Fig. 3), soil coring was even more ineffective in predicting root density at this depth (data not shown).

Standing-crop estimates will always underestimate root system C demands because they do not include accurate estimates of fine-root system (root + mycorrhizae) production and turnover. Estimates of fine-root production and turnover 
Fig. 3. (a) Mean taproot length from the January 1998 root excavation. (b) Mean percentage of lateral-root biomass in the 0$20 \mathrm{~cm}$ soil profile (i.e., lateral-root biomass in $0-20 \mathrm{~cm}$ profile/total lateral-root biomass) from the January 1998 root excavation. Bars represent $\pm \mathrm{SE}, n=3$. Other information as in Fig. 1.
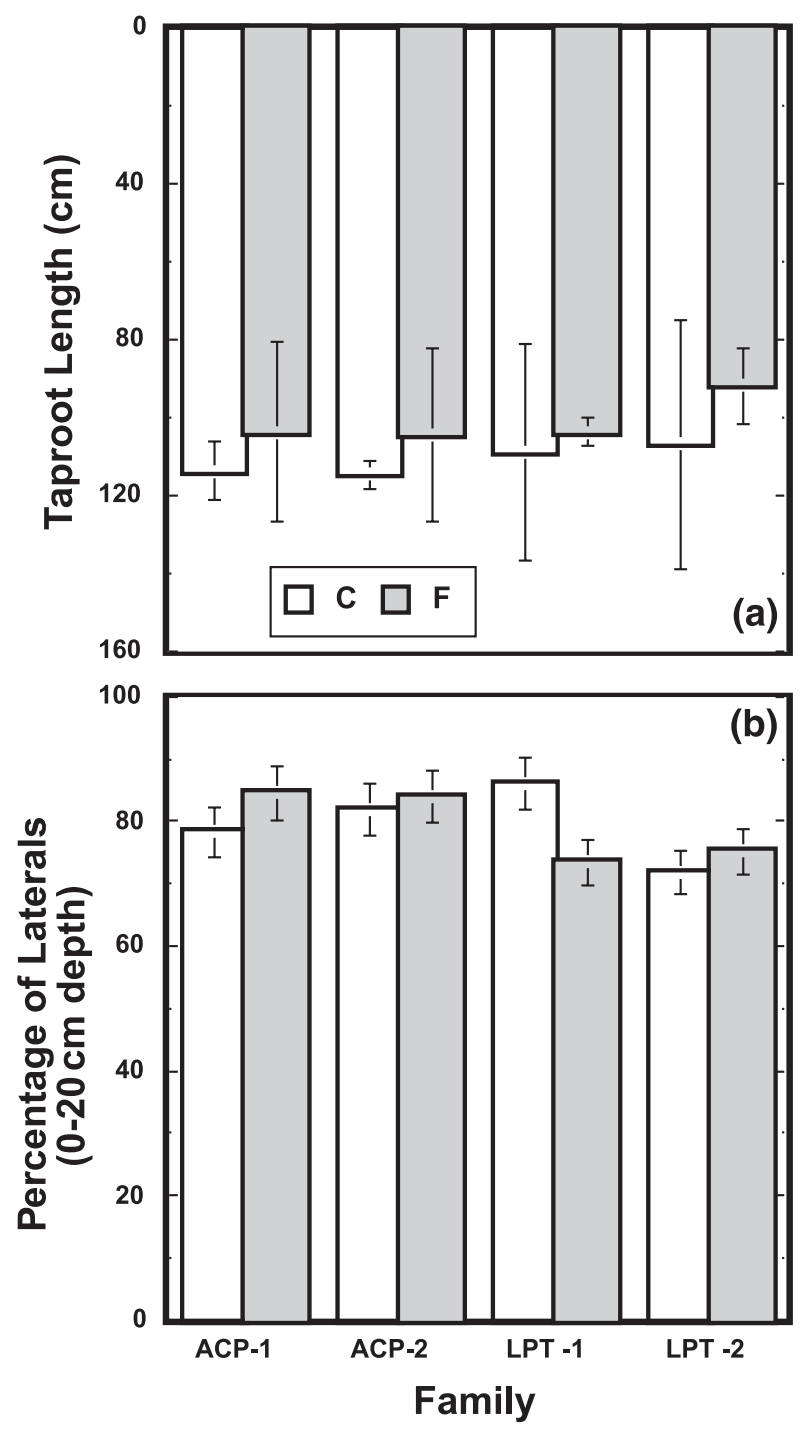

in a loblolly pine plantation have been shown to be as high as $9000 \mathrm{~kg} \cdot \mathrm{ha}^{-1} \cdot \mathrm{year}^{-1}$ (Harris et al. 1977), but more accurate estimates of fine-root production and turnover are becoming available with the advent of more sophisticated in situ techniques.

\section{Allometric analysis}

Since shoot/root ratio and root mass ratios (Fig. 2) are subject to genetic, ontogenetic, and environmental influences, such as light levels, soil fertility, water availability, growth regime, etc. (Ledig et al. 1970; Drew and Ledig 1980; Reynolds and D'Antonio 1996), a more useful measure for assessing treatment effects on biomass allocation during ontogeny is allometric analysis, i.e.,

$$
\log \left(\mathrm{DM}_{\text {shoot }}\right)=a+k \log \left(\mathrm{DM}_{\text {root }}\right)
$$

Table 4. Parameters of the regression $\log (Y)=a+k \log (X)$ for the entire data set $(n=24)$.

\begin{tabular}{lllll}
\hline & $a$ & $k$ & $R^{2}$ & $P$ \\
\hline Shoot DM vs. root DM & -0.2254 & 1.1109 & 0.904 & 0.0001 \\
Root DM vs. tree DM & -0.4929 & 0.9844 & 0.971 & 0.0001 \\
Shoot DM vs. tree DM & -0.8482 & 1.1143 & 0.9114 & 0.0001 \\
Leaf DM vs. tree DM & -0.0294 & 0.8055 & 0.8959 & 0.0001 \\
Stem DM vs. tree DM & -0.6471 & 1.0640 & 0.983 & 0.0001 \\
Branch DM vs. tree DM & -1.3858 & 1.1459 & 0.9462 & 0.0001 \\
Taproot DM vs. tree DM & -1.2923 & 1.1188 & 0.9532 & 0.0001 \\
Coarse + woody root DM & -0.9981 & 0.9984 & 0.9282 & 0.0001 \\
$\quad$ vs. tree DM & & & & \\
\hline
\end{tabular}

Note: Treatment had no significant effect on the regression coefficients $(P=0.05)$, nor on the intercepts $(P>0.09)$. DM, dry mass.

where $a$ is a constant and $k$ is the allometric or regression coefficient of shoot growth on root growth. In the present study, fertilization treatment had no significant effect $(P=$ 0.9380) on the allometric coefficient of shoot dry mass (DM) on root DM ( $k=0.997$ for control, $k=0.974$ for fertilized treatment), nor on the $y$ intercepts $(P=0.2931)$. The allometric coefficient for the complete data set of shoot DM on root DM $(k=1.111)$ is slightly higher or comparable to that reported for southern pine seedlings (e.g., Ledig et al. 1970; Drew and Ledig 1980; Topa and Cheeseman 1992b). In loblolly pine, the balance between shoot and root growth is relatively constant during the first 3 years of growth, with an average allometric coefficient of 0.90 for soil-grown seedlings (Drew and Ledig 1980).

Although fertilization significantly increased tree biomass or tree size, it had no effect on the instantaneous root mass ratio, nor on the allometric relationships between the dry mass of the various above- and below-ground tissues and tree size (Table 4). King et al. (1999) reported small shifts in biomass allocation in field-grown loblolly pine under fertilization, with increased partitioning in perennial belowground tissues (taproots + coarse roots) relative to perennial shoots (branches + stems). In the current study, trees in both the control and fertilized plots allocated more dry mass to perennial (woody) tissues, in particular stems, branches, and taproots, than to foliage. Tree DM had no effect on fine root $\mathrm{DM}$ at any given treatment $(P=0.2891)$. King et al. (1999) similarly found a poor relationship between the dry mass of more ephemeral or short-lived fine roots and that of longlived perennial tissues.

\section{Root distribution}

Over $70 \%$ of lateral roots in all families were found in the 0-20 cm soil horizon (Fig. 3). Although taproots of all families extended down more than $0.9 \mathrm{~m}$ (Fig. 3), we found no proliferation of lateral roots below $40 \mathrm{~cm}$ depth. Existing literature (albeit with seedlings, e.g., van Buijtenen et al. 1976) would suggest that drought-hardy families would have deeper taproots and lateral roots when growing on a deep sandy site (like that at SETRES2). It is possible that as our stand matures and stand water demands increase, both taproots and lateral roots will extend and proliferate into deeper soil horizons.

\section{Carbohydrate partitioning}

Fertilization had little effect on TNC concentrations of 
Fig. 4. Mean total nonstructural carbohydrate (TNC) concentrations in tissues from the whole-tree harvest in January 1998 for each of the four loblolly pine families in control $(\mathrm{C})$ and fertilized (F) plots. Other information as in Fig. $1 ; n=6 . P$ values are reported in Table 5 .

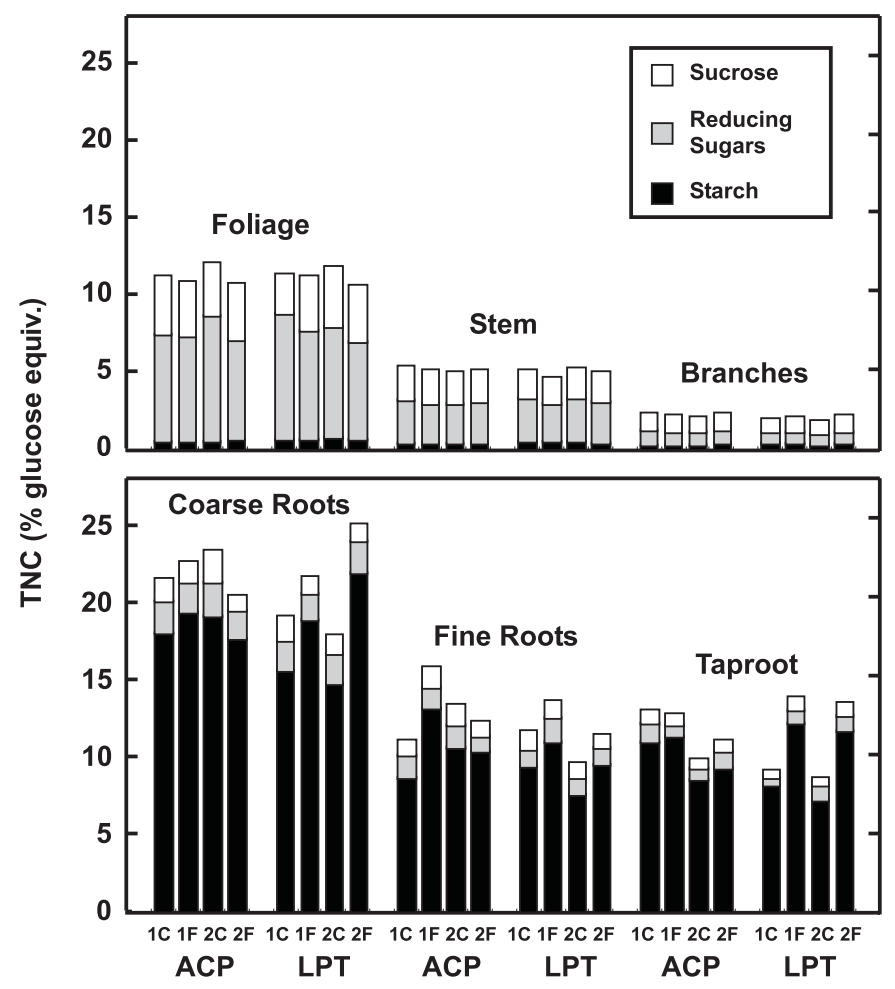

most tissues, with the exception of taproots (Figs. 4 and 5, Table 5). Fertilization increased TNC concentrations of taproots by $21 \%$, primarily because of an increase in absolute starch concentrations. Although starch concentrations of all root tissues of fertilized trees were 15-25\% higher than those of control trees, a treatment effect was only significant in taproots. Similarly, the fertilization treatment had little effect on soluble sugar concentrations, but unlike starch, soluble sugar concentrations were slightly lower $(<6 \%)$ in fertilized trees, mostly because of a decrease in reducing sugars. In aboveground tissues, absolute starch concentrations and partitioning of TNC towards starch were most influenced by provenance and family effects, with LPT families having higher starch concentrations in needles and over $20 \%$ greater partitioning of TNC in starch than ACP families. Treatment $\times$ provenance interactions were not pronounced, nor consistent for carbohydrate concentrations and partitioning in above- and below-ground tissues; when interactions were significant, differences were small $(<5 \%)$.

Field studies with loblolly pine (Adams et al. 1986) and slash pine (Pinus elliottii Engelm. var. elliottii) (Gholz and Cropper 1991) also found minimal fertilization effects on starch and sugar concentrations in above- and below-ground tissues, with seasonal effects being more significant than fertilization. The lack of pronounced fertilization (Adams et al. 1986; Gholz and Cropper 1991; current study) and familyprovenance effects (current study) on tissue carbohydrate storage patterns in southern pines would suggest strong en-
Fig. 5. Mean percentage of total nonstructural carbohydrate (TNC) present as starch in tissues from whole-tree harvest in January 1998 for each of the four loblolly pine families in control (C) and fertilized (F) plots. Note the fivefold difference in the $y$-axis values of above- and below-ground tissue. Other information as in Fig. $1 ; n=6 . P$ values are reported in Table 5 .

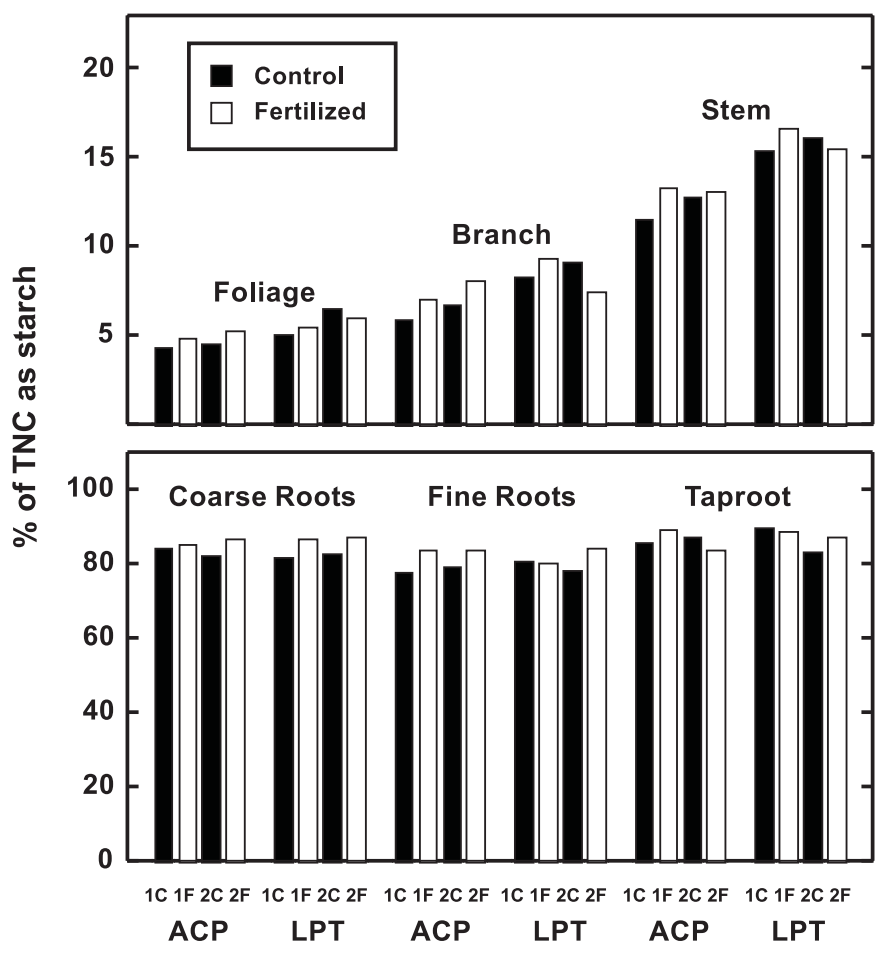

dogenous control over partitioning of fixed $\mathrm{C}$ to storage in field trees. A strong seasonal influence on starch concentrations in southern pines is not unexpected given the dynamic or seasonal nature of photosynthesis and shoot and root growth. Starch concentrations in above- and below-ground tissues are generally highest in the spring, near the time of spring bud burst and production of new twig, needle, and stem growth (Adams et al. 1986; Cranswick et al. 1987; Gholz and Cropper 1991). The lowest seasonal concentrations of starch vary with tissue type, but in southern pines, concentrations are often lowest in late fall or early winter (Adams et al. 1986; Gholz and Cropper 1991), when photosynthetic rates are at their lowest and the metabolic dependency on $\mathrm{C}$ stores may be at its highest. In contrast, sugar concentrations in above- and below-ground tissues of slash pine exhibit little seasonality (Gholz and Cropper 1991).

In the present study, the largest differences in absolute TNC concentrations and carbohydrate partitioning were found between above- and below-ground tissues. Needles had the greatest TNC concentrations of any aboveground tissue, exhibiting twice as much as branches and five times as much as stems (Fig. 4). Since first- and second-flush needles from the 1997 growing season contained similar concentrations of TNC, only first flush is shown as representative data. All root tissues had higher concentrations of TNC than branches or stems (Fig. 4), with coarse roots exhibiting the highest TNC concentrations of any tissue. Although fine roots, taproots, and needles had similar TNC concentrations, over $75 \%$ 
Table 5. $P$ values from the ANOVA for total nonstructural carbohydrate (TNC) (Fig. 4), starch, soluble sugars, and percentage of TNC present as starch (Fig. 5) in tissue from whole-tree harvest in January 1998.

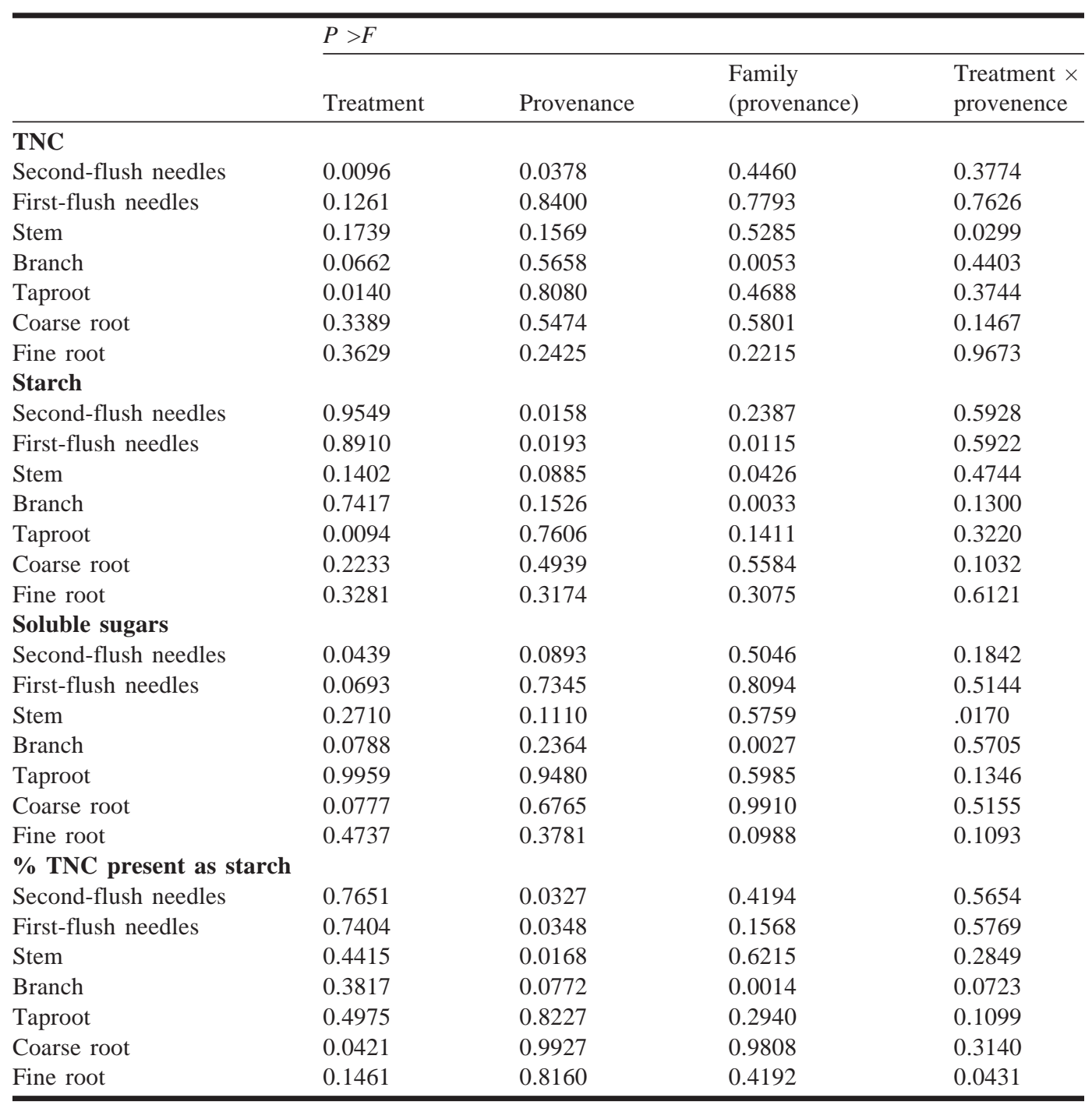

of TNC in all root tissues were partitioned towards starch, compared with only $6 \%$ in needles (Fig. 5).

Gholz and Cropper (1991) estimated that coarse roots (defined as roots $>20 \mathrm{~mm}$ in diameter) of slash pine stored more than one-half of the starch accumulated over 1 year, even though they represented only $15 \%$ of the total tree biomass. However, starch pools of slash pine roots in the $<20 \mathrm{~mm}$ root diameter classes and taproots were not examined. In the current study, more than $90 \%$ of total tree starch in January was stored in the roots of loblolly pine (even though roots collectively represented less than $30 \%$ of total tree biomass) (Fig. 6). Based upon biomass, the highest percentage of tree starch was stored in the larger woody root classes, i.e., taproots $(35 \%)$ and woody roots $(32 \%)$, while coarse and fine roots accounted for 14 and $12 \%$ of tree starch, respectively.

Both the absolute TNC and partitioning data in the current study suggest that roots, more than aboveground tissues, function as storage organs for carbohydrate reserves in loblolly pine during the winter. Starch accumulation in loblolly pine needles occurs when photosynthetic rates exceed metabolic demands of needle tissue and rates of transport out of fo-
Fig. 6. Mean percentage of total tree starch in various root tissues from whole-tree harvest in January 1998 for each of the four loblolly pine families in control (C) and fertilized (F) plots. Other information as in Fig. 1.

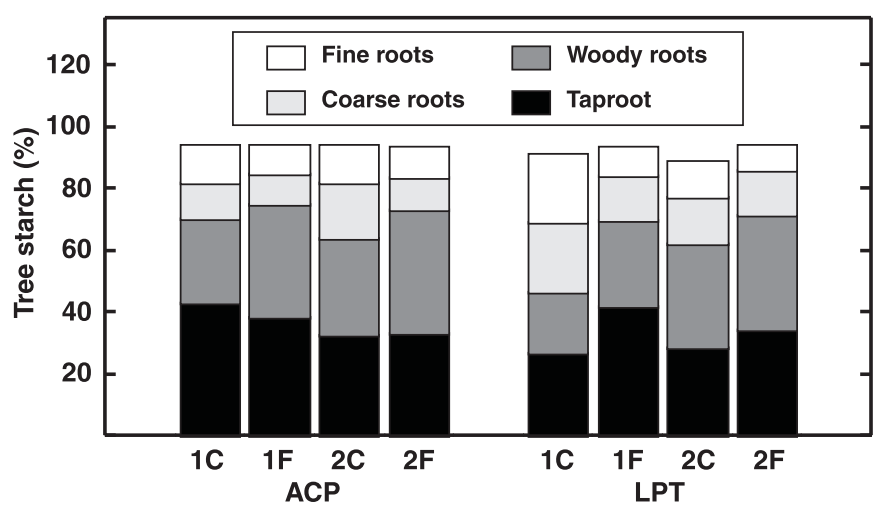


Table 6. Mean percentage of soluble sugars present as sucrose in tissues of loblolly pine from the whole-tree harvest in January 1998.

\begin{tabular}{ll}
\hline First-flush needles & $33.0 \pm 1.7$ \\
Second-flush needles & $32.4 \pm 1.7$ \\
Branch & $42.0 \pm 0.5$ \\
Stem & $55.2 \pm 0.5$ \\
Coarse roots & $40.1 \pm 1.2$ \\
Fine roots & $47.4 \pm 1.1$ \\
Taproot & $44.7 \pm 1.5$ \\
\hline
\end{tabular}

Note: Since there were no significant family(provenance), provenance, and treatment differences $(P>0.05)$, data were pooled. Values are means \pm SE, $n=48$.

liage (Kuehny and Topa 1998). During the late winter, any net $\mathrm{C}$ gain in needles from photosynthesis would be expected to be low (Murthy et al. 1997), with recently acquired $\mathrm{C}$ being utilized to support the metabolic demands of the closest $\mathrm{C}$ sinks, i.e., needle and perhaps branch tissues. The carbohydrate partitioning data, in particular the low percentage of TNC present as starch, suggests that needle (and most likely branch and stem) metabolism is probably being supplemented with stored $\mathrm{C}$ from root tissues. Increased partitioning of soluble sugars to sucrose in stems suggests remobilization of stored $\mathrm{C}$ for transport to $\mathrm{C}$ sinks (Table 6). However, it is also possible that sucrose may be a form of $\mathrm{C}$ storage in these tissues (Kuehny and Topa 1998).

Our TNC data do not suggest that genetic differences in aboveground growth are the result of differences in $\mathrm{C}$ partitioning to the various TNC fractions. Overall, our data also suggest (tempered by our constrained sample size) that genetic differences in $\mathrm{C}$ allocation to belowground biomass in loblolly pine is not a contributing factor towards differences in aboveground growth. However, our conclusion is based on standing-crop biomass estimates at one time point in the juvenile life stage. Slower-growing families could have higher root system $\mathrm{C}$ demands because of greater fine-root production and turnover and we are currently investigating this possibility. It is also possible that a greater investment in fineroot production during the juvenile life stage may ultimately result in faster growth once the canopy closes and root competition for soil resources becomes more intense. One would expect that some identifiable physiological character would be key to define the growth capacity of each genotype. Genotypes that produce high stem volume may grow fast for many different reasons (e.g., McKeand and Svensson 1997). A recent report found that family differences in cumulative height of loblolly pine diverged between ages 4 to 11 years, suggesting that the probability of identifying changes in growth capacity are plausible (Svensson et al. 1999). We will continue to monitor trees in this stand as they progress from the juvenile to mature life stage and the competition for light and soil resources increases to determine whether one or multiple characters is strongly associated with growth capacity.

\section{Acknowledgements}

This research was conducted by the Boyce Thompson Institute for Plant Research and North Carolina State Univer- sity as part of cooperative agreement U.S. Department of Energy Agenda 2020 Sustainable Forestry Research Initiative No. DE-FC07-97ID13527. Additional funds were provided by the endowment of the Boyce Thompson Institute for Plant Research, the North Carolina State University Tree Improvement Program, the North Carolina State University Forest Nutrition Cooperative, Bowater Inc., Champion International, Georgia-Pacific Corp. (now The Timber Company), Rayonier, Westvaco, Weyerhauser Company, and Southern Illinois University Edwardsville. Thanks are due to all the shoot processors and root excavators in January 1998. This manuscript has not been subject to U.S. Department of Energy review and should not be construed to represent policies of this agency.

\section{References}

Adams, M.B., Allen, H.L., and Davey, C.B. 1986. Accumulation of starch in roots and foliage of loblolly pine (Pinus taeda L.): effects of season, site, and fertilization. Tree Physiol. 2: 35-46.

Ågren, G.I., Axelsson, B., Flower-Ellis, J.G., Linder, S., Person, H., Staaf, H., and Troeng, E. 1980. Annual carbon budget for a young Scots pine. Ecol. Bull. 32: 307-313.

Albaugh, T.J., Allen, H.L., Dougherty, P.M., Kress, L.W., and King, J.S. 1998. Leaf-area and above- and belowground growth responses of loblolly pine to nutrient and water additions. For. Sci. 44: 317-328.

Baldwin, V.C., Jr. 1987. Green and dry-weight equations for aboveground components of planted loblolly pine trees in the west gulf region. South. J. Appl. For. 11: 212-218.

Bongarten, B.C., and Teskey, R.O. 1987. Dry weight partitioning and its relationship to productivity in loblolly pine seedlings from seven sources. For. Sci. 33: 255-267.

Cranswick, A.M., Rook, D.A., and Zabkiewicz, J.A. 1987. Seasonal changes in carbohydrate concentration and composition of different tissue types of Pinus radiata trees. N.Z. J. For. Sci. 17: 121-130.

Drew, A.P., and Ledig, F.T. 1980. Episodic growth and relative shoot:root balance in loblolly pine seedlings. Ann. Bot. 45: 143 148.

Geiger, D.R., and Servaites, J.C. 1994. Diurnal regulation of photosynthetic carbon metabolism in $\mathrm{C}_{3}$ plants. Ann. Rev. Plant Physiol. Plant Mol. Biol. 45: 235-256.

Gholz, H.L., and Cropper, W.P., Jr. 1991. Carbohydrate dynamics in mature Pinus elliotti var. elliottii trees. Can. J. For. Res. 21: 1742-1747.

Greenwood, M.S., and Volkaert, H.A. 1992. Morphophysiological traits as markers for the early selection of conifer families. Can. J. For. Res. 22: 1001-1008.

Harris, W.F., Kinerson, R.S., Jr., and Edwards, N.T. 1977. Comparison of belowground biomass of natural deciduous forest and loblolly pine plantations. Pedobiologia, 17: 369-381.

Hockman, J.N., and Allen, H.L. 1990. Nutritional diagnosis in young loblolly pine stands using a DRIS approach. In Sustained productivity of forest soils. Edited by S.P. Gessel, D.S. Lacate, G.F. Weetman, and R.F. Powers. University of British Columbia, Faculty of Forestry Publication, Vancouver. pp. 500-514.

Johnson, M.G., Phillips, D.L., Tingey, D.T., and Storm, M.J. 2000. Effects of elevated $\mathrm{CO}_{2}, \mathrm{~N}$-fertilization, and season on survival of ponderosa pine roots. Can J. For. Res. 30: 220-228.

Jones, M.G.K., Outlaw, W.H., Jr., and Lowry, O.H. 1977. Enzymic assay of $10^{-7}$ to $10^{-14}$ moles of sucrose in plant tissues. Plant Physiol. 60: 379-383. 
King, J.S., Albaugh, T.J., Allen, H.L., and Kress, L.W. 1999. Standlevel allometry in Pinus taeda as affected by irrigation and fertilization. Tree Physiol. 19: 769-778.

Kuehny, J.S., and Topa, M.A. 1998. Diurnal changes in allocation and partitioning of recently assimilated carbon in loblolly pine seedlings. Physiol. Plant. 104: 317-328.

Ledig, F.T., Bormann, F., and Wenger, K.F. 1970. The distribution of dry matter growth between shoot and roots in loblolly pine. Bot. Gaz. 131: 349-359.

Li, B., Allen, H.L., and McKeand, S.E. 1991. Nitrogen and family effects on biomass allocation of loblolly pine seedlings. For. Sci. 37: 271-283.

Majdi, H., and Nylund, J.-E. 1996. Does liquid fertilization affect fine root dynamics and lifespan of mycorrhizal short roots? Plant Soil, 185: 305-309.

McKeand, S.E., and Svensson, J. 1997. Sustainable management of genetic resources. J. For. 94: 4-9.

McKeand, S.E., Grissom, J.E., Handest, J.A., O’Malley, D.M., and Allen, H.L. 1999. Responsiveness of diverse provenances of loblolly pine to fertilization-age 4 results. J. Sustain. For. 10: 87-94.

Murthy, R., Zarnoch, S.J., and Dougherty, P.M. 1997. Seasonal trends of light-saturated net photosynthesis and stomatal conductance of loblolly pine trees grown in contrasting environments of nutrition, water and carbon dioxide. Plant Cell Environ. 20: 558-568.

Pregitzer, K.S., Hendrick, R.L., and Fogel, R. 1993. The demography of fine roots in response to patches of water and nitrogen. New Phytol. 125: 575-580.

Reichle, D.E., Dinger, B.E., Edwards, N.T., Harris, W.F., and Sollins, P. 1973. Carbon flow and storage in a forest ecosystem. In Carbon and biosphere. Edited by G.M. Woodwell and E.V. Pecan. U.S. Atomic Energy Commission, Springfield, Va. pp. 345-365.

Reynolds, H.L., and D'Antonio, C. 1996. The ecological significance of plasticity in root weight ratio in response to nitrogen: Opinion. Plant Soil, 185: 75-97.

Shelton, M.G., Nelson, L.E., and Switzer, G.L. 1984. The weight, volume and nutrient status of plantation-grown loblolly pine trees in the interior flatwoods of Mississippi. Miss. Agric. Exp. Stn. Tech. Bull. 121, Mississippi State University, Starkville.

Svensson, J., McKeand, S.E., Allen, H.L., and Campbell, R.G. 1999. Genetic variation in height and volume of loblolly pine open-pollinated families during canopy closure. Silvae Genet. 48: 204-208.

Tingey, D.T., Johnson, M.G., Phillips, D.L., Johnson, D.W., and Ball, J.T. 1996. Effects of elevated $\mathrm{CO}_{2}$ and nitrogen on the synchrony of shoot and root growth in ponderosa pine. Tree Physiol. 16: 905-914.

Topa, M.A., and Cheeseman, J.M. 1992a. Carbon and phosphorus partitioning in Pinus serotina seedlings growing under hypoxic and low-P conditions. Tree Physiol. 10: 195-207.

Topa, M.A., and Cheeseman, J.M. 1992b. Effects of root hypoxia and a low $\mathrm{P}$ supply on relative growth, carbon dioxide exchange rates and carbon partitioning in Pinus serotina seedlings. Physiol. Plant. 86: 136-144.

Topa, M.A., and Sisak, C.L. 1997. Characterization of phosphorus uptake in slow- and fast-growing southern pine seedlings grown in solution culture. Plant Soil, 190: 317-329.

van Buijtenen, J.P., Bilan, M.V., and Zimmerman, R.H. 1976. Morpho-physiological characteristics related to drought resistance in Pinus taeda. In Tree physiology and yield improvement. Edited by M.G.R. Cannell and F.T. Last. Academic Press, London. pp. 349-359.

Van Lear, D.H., and Kapeluck, P.R. 1995. Above- and belowstump biomass and nutrient content of a mature loblolly pine plantation. Can. J. For. Res. 25: 361-367.

Van Lear, D.H., Taras, M.A., Waide, J.B., and Augspurger, M.K. 1986. Comparison of biomass equations for planted vs. natural loblolly pine stands of sawtimber size. For. Ecol. Manag. 14: 205-210.

Vogt, K.A., and Persson, H. 1991. Measuring growth and development of roots. In Techniques and approaches in forest tree physiology. Edited by J.P. Lassoie and T.M. Hinckley. CRC Press, Boca Raton, Fla. pp. 477-501. 